\title{
PENENTUAN JUMLAH PRODUKSI TAHU DENGAN MENGGUNAKAN METODE FUZZY TSUKAMOTO PADA UKM ABADI BERBASIS WEB
}

\author{
Wanda Ilham ${ }^{1}$, Nurman Fajri ${ }^{2}$ \\ ${ }^{1)}$ Universitas Catur Insan Cendekia Jl. Kesambi, Drajat, Kesambi, Kota Cirebon, Jawa Barat 45133 \\ ${ }^{2}$ Universitas Putra Indonesia "YPTK" Padang \\ e-mail: wandailham@cic.ac.id ${ }^{1}$, fajriupi@gmail.com²
}

\begin{abstract}
Abstrak
Keuntungan yang maksimal diperoleh dari penjualan yang maksimal. Penjualan yang maksimal yaitu yang dapat memenuhi permintaan-permintaan yang ada. Adanya penentuan jumlah produksi yang direncanakan untuk memenuhi tingkat produksi guna memenuhi tingkat penjualan yang direncanakan atau tingkat permintaan pasar. Faktor-faktor yang perlu diperhatikan dalam menentukan jumlah produksi, antara lain: jumlah persediaan dan jumlah permintaan. Jumlah permintaan dan persediaan merupakan suatu ketidakpastian. Logika fuzzy merupakan salah satu ilmu yang dapat menganalisa ketidakpastian. Usaha kecil dan menengah Abadi dalam memproduksi tahu tentu nya menyesuaikan dengan keinginan serta kebutuhan pelanggannya, Sementara kebutuhan dan minat pelanggan terhadap hasil produksi usaha abadi selalu berubah ubah setiap waktunya. Selain upaya memenuhi keinginan dan kebutuhan para pelanggan, Usaha Kecil dan Menengah Abadi juga perlu memperhatikan kapasitas produksi yang di milikinya tersebut, minimalisasi produk sisa dan dapat menentukan jumlah produksi tahu pada hari ini dan selanjutnya. Dengan menggunakan aplikasi ini diharapkan dapat memberikan kemudahan bagi pihak perusahaan untuk memprediksi jumlah produksi berdasarkan jumlah permintaan dan data persediaan yang ada, agar dapat mencapai produksi yang optimal.
\end{abstract}

Kata kunci: Metode Fuzzy Tsukamoto, PHP MySQL, Permintaan, Persediaan, Produksi

The maximum profit is obtained from maximum sales. Maximum sales, that is, which can meet existing demands. The determination of the amount of production planned to meet the level of production in order to meet the level of planned sales or the level of market demand. Factors that need to be considered in determining the amount of production include: the amount of inventory and the amount of demand. The amount of demand and supply is an uncertainty. Fuzzy logic is one of the sciences that can analyze uncertainty.Abadi's small and medium-sized business in producing tofu certainly adapts to the desires and needs of its customers, While the needs and interests of customers towards the results of the production of a perpetual business always changes every time. In addition to efforts to meet the desires and needs of customers, the Small and Medium Enterprise Abadi also needs to pay attention to the production capacity it has, minimize the residual products and be able to determine the amount of tofu production today and beyond. By using this application it is expected to provide convenience for the company to predict the amount of production based on the number of requests and existing inventory data, in order to achieve optimal production.

Keywords: Tsukamoto Fuzzy Method, PHP MySQL, Demand, Inventory, Production

\section{PENDAHULUAN}

Tahu adalah sebuah makanan yang familiar di kalangan masyarakat Indonesia. Selain harga yang murah dan mudah untuk di dapat, tahu mengandung nilai protein yang tinggi, karena bahan baku utamanya adalah kedelai. Hampir diseluruh kalangan masyarakat Indonesia mengkonsumsi tahu. Bahan baku utama nya ialah kedelai. 
Pada dasarnya penentuan jumlah produksi ini direncanakan untuk memenuhi tingkat produksi guna memenuhi tingkat penjualan yang di rencanakan atau tingkat permintaan pasar. Usaha kecil dan menengah Abadi dalam memproduksi tahu tentunya menyesuaikan dengan keinginan serta kebutuhan pelanggannya, Sementara kebutuhan dan minat pelanggan terhadap hasil produksi usaha Abadi selalu berubah ubah setiap waktunya. Selain upaya memenuhi keinginan dan kebutuhan para pelanggan, usaha kecil abadi juga perlu memperhatikan kapasitas produksi yang di milikinya tersebut, minimalisasi produk sisa dan mencapai maksimasi keuntungan bagi usahanya.

Logika Fuzzy merupakan ilmu yang mempelajari mengenai ketidakpastian. Logika fuzzy diyakini sangat fleksibel dan memiliki toleransi terhadap data-data yang ada. Dengan berdasarkan logika fuzzy, akan dihasilkan suatu model dari suatu sistem yang mampu memperkirakan jumlah produksi. Faktor-faktor yang mempengaruhi dan menentukan jumlah produksi dengan logika fuzzy antara lain jumlah permintaan dan jumlah persediaan (Djunaidi, dkk, 2005).

Dengan adanya masalah tersebut maka untuk menentukan jumlah produksi dalam memenuhi permintaan konsumen diperlukan suatu alternatif pemecahan masalah tanpa menambah fasilitas yang ada, yaitu dengan mengaplikasikan logika fuzzy Tsukamoto. Penerapan logika fuzzy Tsukamoto dalam perencanaan jumlah produksi tempe, diharapkan perusahaan dapat mengatasi fluktuasi permintaan konsumen dengan biaya produksi yang minimal.

\section{KAJIAN PUSTAKA}

\subsection{Rekayasa Perangkat Lunak}

Rekayasa perangkat lunak (software engineering) merupakan pembangunan dengan menggunakan prinsip atau konsep rekayasa dengan tujuan menghasilkan perangkat lunak yang bernilai ekonomi yang dipercaya dengan bekerja secara efisien menggunakan mesin. Perangkat lunak banyak dibuat dan pada akhirnya sering tidak digunakan karena tidak memenuhhi kebutuhan pelanggan atau bahkan Karena masalah non-teknis seperti enggan pemakai perangkat lunak (user) untuk mengubah caara kerja dari manual ke otomatis atau ketidakmampuan user menggunakan komputer. Oleh karena itu, rekayasa perangkat lunak dibutuhkan agar perangkat lunak yang dibuat tidak hanya menajdi perangkat lunak yang tidak terpakai (Rosa A.S., M.Shalahuddin, 2013).

\subsection{UML(Unified Modelling Language $)$}

Unified Modelling Language (UML) adalah sebuah "bahasa" yg telah menjadi standar dalam industri untuk visualisasi, merancang dan mendokumentasikan sistem perangkat lunak. UML menawarkan sebuah standar untuk merancang model sebuah sistem. (Wahono, R.S, 2003).

\subsection{Artificial Intelligence}

Kecerdasan Buatan adalah suatu ilmu yang mempelajari cara membuat komputer melakukan sesuatu seperti yang dilakukan oleh manusia (Minsky, 1989).

Kecerdasan Buatan (artificial intelligence) merupakan kawasan penelitian, aplikasi dan instruksi yang terkait dengan pemograman komputer untuk melakukan sesuatu hal yang ddalam pandangan manusia adalah cerdas (H. A. Simon, 1987).

Ada tiga tujuan kecerdasan buatan, yaitu: membuat komputer lebih cerdas, mengerti tentang kecerdasan, dan membuat mesin lebih berguna (Winston dan Prendergast, 1994).

Kecerdasan buatan berbeda dengan program konvensional. Pemograman konvensional berbasis pada algorithma yang mendefinisikan setiap langkah dalam penyelesaian masalah. Program konvensional dapat menggunakan rumus matematika atau prosedur sekuensial untuk menghasilkan solusi. Pemograman dalam kecerdasan buatan yang berbasis pada representasi symbol dan manipulasi (Turban, 1995).

\section{$2.4 \quad$ Fuzzy Logic}

Konsep tentang logika fuzzy diperkenalkan oleh Prof. Lotfi Astor Zadeh pada tahun 1962. Logika fuzzy adalah metodologi sistem control pemecahan masalah, yang cocok untuk diimplementasikan pada sistem, mulai dari sistem yang sederhana, sistem kecil, embedded system, jaringan PC, multi-channel atau workstation berbasis akuisisi data, dan system control. Metodologi ini dapat diterapkan pada perangkat keras, perangkat lunak, atau kombinasi keduanya (Sutojo, dkk, 2010). 
Dalam logika klasik dinyatakan bahwa segala sesuatu bersifat biner, yang artinya adalah hanya mempunyai dua kemungkinan. Oleh karena itu, semua ini dapat mempunyai nilai keanggotaan 0 atau 1. Akan tetapi, dalam logika fuzzy memungkinkan nilai keanggotaan berada antara 0 dan 1 . Artinya bisa saja suatu keadaan mempunyai dua nilai secara bersamaan, namun besar nilainya tergantung pada bobot keanggotaan yang dimilikinya (Sutojo, dkk, 2010).

Menurut Sri Kusumadewi dan Purnomo Hari logika fuzzy dikatakan sebagai logika baru yang lama, sebab ilmu tentang logika fuzzy yang modern dan metodis baru ditemukan beberapa tahun yang lalu, padahal sebenarnya konsep tentang logika fuzzy itu sendiri sudah ada pada diri kita sejak lama (Muhammad Yunus, Sandi Badi Wibowo Atim, 2013).

\subsection{Metode Tsukamoto}

Pada metode Tsukamoto, setiap konsekuen pada aturan yang berbentuk IF-THEN harus direpresentasikan dengan suatu himpunan fuzzy dengan fungsi keanggotaan yang monoton (Sri Kusumadewi, 2003).

\subsection{Metode Sugeno}

Dalam metode Sugeno, output sistem berupa konstanta atau persamaan linear. Metode ini diperkenalkan oleh Takagi-Sugeno Kang pada 1985 (Sutojo, dkk, 2010).

\subsection{Metode Mamdani}

Metode Mamdani sering juga dikenal dengan nama Metode Max-Min. Metode ini diperkenalkan oleh Ebrahim Mamdani pada tahun 1975. Untuk mendapatkan output, diperlukan 4 tahapan (Sri Kusumadewi, 2003) :

1. Pembentukan himpunan fuzzy

Pada Metode Mamdani, baik variable input maupun variable output dibagi menjadi satu atau lebih himpunan fuzzy.

2. Aplikasi fungsi implikasi (aturan)

Pada Metode Mamdani, fungsi implikasi yang digunakan adalah Min.

3. Komposisi aturan

Tidak seperti penalaran monoton, apabila sistem terdiri dari beberapa aturan, maka inferensi diperoleh dari kumpulan dan korelasi antar aturan. Ada 3 metode yang digunakan dalam melakukan inferensi sistem fuzzy, yaitu : max, additive, dan probabilistik OR (probor).

a. Metode Max (Maximum)

Pada metode ini, solusi himpunan fuzzy diperoleh dengan cara mengambil nilai maksimum aturan, kemudian menggunakannya untuk memodifikasi daerah fuzzy, dan mengaplikasikannya ke output dengan menggunakan operator OR (union). Jika semua proposisi telah dievaluasi, maka output akan berisi suatu himpunan fuzzy yang merefleksikan kontribusi dari tiap-tiap proposisi. Secara umum dapat dituliskan :

$$
\mu_{s f}\left[x_{i}\right] \leftarrow \max \left(\mu_{s f}\left[x_{i}\right], \mu_{k f}\left[x_{i}\right]\right)
$$

Dengan :

$\mu_{s f}\left[x_{i}\right]=$ nilai keanggotaan solusi fuzzy sampai aturan ke-i;

$\mu_{k f}\left[x_{i}\right]=$ nilai keanggotaan konsekuen fuzzy aturan ke-i;

Apabila digunakan fungsi implikasi MIN, maka metode komposisi ini sering disebut dengan nama MAX-MIN atau MIN-MAX atau MAMDANI.

b. Metode Additive (Sum)

Pada metode ini, solusi himpunan fuzzy diperoleh dengan cara melakukan bounded-sum terhadap semua output daerah fuzzy. Secara umum dituliskan :

$$
\mu_{s f}\left[x_{i}\right] \leftarrow \min \left(1, \mu_{s f}\left[x_{i}\right]+\mu_{k f}\left[x_{i}\right]\right)
$$


Dengan :

$\mu_{s f}\left[x_{i}\right]=$ nilai keanggotaan solusi fuzzy sampai aturan ke-i;

$\mu_{k f}\left[x_{i}\right]=$ nilai keanggotaan konsekuen fuzzy aturan ke-i;

c. Metode Probabilistik OR (probor)

Pada metode ini, solusi himpunan fuzzy diperoleh dengan cara melakukan product terhadap semua output daerah fuzzy. Secara umum dituliskan :

$\mu_{s f}\left[x_{i}\right] \leftarrow\left(\mu_{s f}\left[x_{i}\right]+\mu_{k f}\left[x_{i}\right]\right)-\left(\mu_{s f}\left[x_{i}\right] * \mu_{k f}\left[x_{i}\right]\right)$

Dengan :

$\mu_{s f}\left[x_{i}\right]=$ nilai keanggotaan solusi fuzzy sampai aturan ke-i;

$\mu_{k f}\left[x_{i}\right]=$ nilai keanggotaan konsekuen fuzzy aturan ke-i;

4. Penegasan (defuzzy)

Input dari proses defuzzifikasi adalah suatu himpunan fuzzy yang diperoleh dari komposisi aturanaturan fuzzy, sedangkan output yang dihasilkan merupaka suatu bilangan pada domain himpunan fuzzy tersebut. Sehingga jika diberikan suatu himpunan fuzzy dalam range tertentu, maka harus dapat diambil suatu nilai crsip tertentu sebagai output.

Ada beberapa metode defuzzifikasi pada komposisi aturan Mamdani, antara lain :

a. Metode Centroid (Composite Moment)

Pada metode ini, solusi crisp diperoleh dengan cara mengambil titik pusat $\left(\mathrm{z}^{*}\right)$ daerah fuzzy.

Secara umum dirumuskan :

$$
\begin{aligned}
& z^{*}=\frac{\int_{z} z \mu(z) d z}{\int_{z} \mu(z) d z} \rightarrow \text { untuk semesta kontiniu } \\
& z^{*}=\frac{\sum_{j=1}^{n} z_{j} \mu\left(z_{j}\right)}{\sum_{j=1}^{n} \mu\left(z_{j}\right)} \rightarrow \text { untuk semesta diskret }
\end{aligned}
$$

b. Metode Bisektor

Pada metode ini, solusi crisp diperoleh dengan cara mengambil nilai pada domain fuzzy yang memiliki nilai keanggotaan separo dari jumlah total nilai keanggotaan pada daerah fuzzy. Secara umum dituliskan :

$$
z_{p} \text { sedemikian hingga } \int_{\Re_{1}}^{p} \mu(z) d z=\int_{p}^{\Re / n} \mu(z) d z
$$

c. Metode Mean of Maximum (MOM)

Pada meode ini, solusi crisp diperoleh dengan cara mengambil nilai rata-rata domain yang memiliki nilai keanggotaan maksimum.

d. Metode Largest of Maximum (LOM)

Pada metode ini, solusi crisp diperoleh dengan cara mengambil nilai terbesar dari domain yang memiliki nilai keagggotaan maksimum.

e. Metode Smallest of Maximum (SOM)

Pada meode ini, solusi crisp diperoleh dengan cara mengambil nilai terkecil dari domain yang memiliki nilai keanggotaan maksimum.

\section{METODOLOGI}

\subsection{Identifikasi Variabel Sistem}

Pada tahap ini, nilai keanggotaan himpunan permintaan dan persediaan dicari menggunakan fungsi keanggotaan himpunan fuzzy dengan memperhatikan nilai maksimum dan minimum data dari bulan terakhir dari setiap variabel. Adapun variabelnya antara lain : variabel permintaan, variabel persediaan dan variabel produksi. 
1. Permintaan

Jumlah kebutuhan konsumen akan barang yang akan dihasilkan oleh perusahaan biasanya jumlahnya terbatas, sehingga permintaan merupakan salah satu batasan atau kendala dalam perencanaan jumlah produksi perusahaan.

2. Persediaan

Persediaan merupakan pengadaan barang yang disimpan digudang guna sebagai cadangan akan permintaan.

Produksi Produksi merupakan jumlah yang akan diproduksi suatu perusahaan yang akan mempertimbangkan kebutuhan konsumen akan barang dan persediaan yang dimiliki oleh perusahaan.

\subsection{Himpunan Fuzzy}

Untuk memperoleh jumlah produksi yang optimal menggunakan metode fuzzy Mamdani, variabel fuzzy yang digunakan terdiri dari Permintaan (X), Persediaan (Y), dan Produksi (Z).

\subsection{Semesta Pembicaraan}

Untuk memperoleh data maksimum dan minimum jumlah permintaan, persediaan, dan produksi yaitu dengan dicari data yang maksimum dan minimum selama sebulan terakhir pada data produksi, seperti disajikan sebagai berikut :

Tabel 1. Semesta Pembicaraan

\begin{tabular}{|c|c|c|}
\hline \multirow{2}{*}{ Fungsi } & Variabel & $\begin{array}{c}\text { Semesta Pembicaraan } \\
\text { (gr) }\end{array}$ \\
\hline \multirow{2}{*}{ Input } & Permintaan & $7040-8060$ \\
\cline { 2 - 3 } & Persediaan & $1020-2040$ \\
\hline Output & Produksi & $7500-7940$ \\
\hline
\end{tabular}

\subsection{Pembentukan Rule}

Rule merupakan serangkaian aturan sebagai dasar perhitungan yang akan dilakukan, aturan-aturan yang relevan didapat dari history aktivitas produksi pada Rumah Tempe Samini.

\subsection{Proses Perhitungan Logika Fuzzy (Tsukamoto)}

Data-data yang di dapat di UKM abadi digunakan untuk mengimplementasikan metode Logika Fuzzy (Tsukamoto) untuk menentukan jumlah produksi hari selanjutnya berdasarkan data persediaan dan permintaan.

\subsection{Perancangan Sistem Menggunakan UML}

Perancangan aplikasi Fuzzy Logic ini dirancang menggunakan alat bantu berupa UML (Unified Modelling Language) agar mempermudah memindahkan konsep sistem yang dirancang ke dalam bentuk program, dimana perancangannya digambarkan dalam bentuk diagram-diagram. Adapun dalam perancangan aplikasi ini penulis menggunakan 7 (tujuh) diagram UML diantaranya sebagai berikut : 


\subsubsection{Use Case Diagram}

Use Case diagram menggambarkan bagaimana proses-proses yang dilakukan oleh aktor terhadap sebuah sistem. Ada 1 aktor yang terlibat dalam aplikasi Fuzzy logic ini yaitu admin.

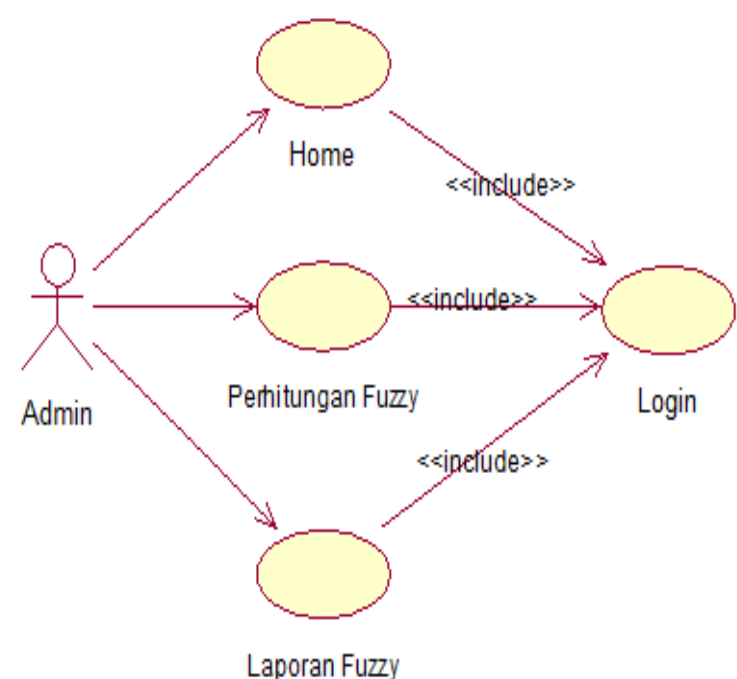

Gambar 1. Use Case Diagram

Admin dalam sistem ini bisa melihat langsung tampilan aplikasi dengan login terlebih dahulu. Dalam admin dapat melakukan aktifitas pada home, perhitungan fuzzy dan laporan fuzzy.

\subsubsection{Class Diagram}

Class diagram menggambarkan bagaimana struktur dari perancangan sistem. Semua proses yang dilakukan oleh aktor terhadap aplikasi akan didefinisikan dengan menggunakan class diagram. Class diagram menunjukkan bentuk visualisasi dalam pembuatan sistem. Masing-masing class memiliki attribute dan metoda / fungsi sesuai dengan proses yang terjadi.

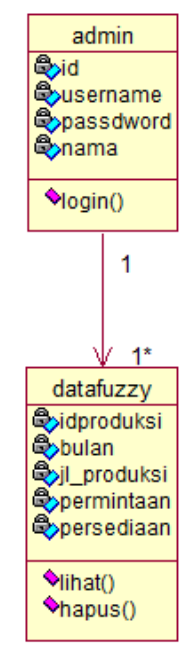

Gambar 2. Class Diagram 


\subsubsection{Sequence Diagram}

Sequence diagram menjelaskan interaksi objek yang disusun berdasarkan urutan waktu. Secara mudahnya sequence diagram adalah gambaran tahap demi tahap yang seharusnya dilakukan untuk menghasilkan suatu sistem sesuai dengan use case diagram.

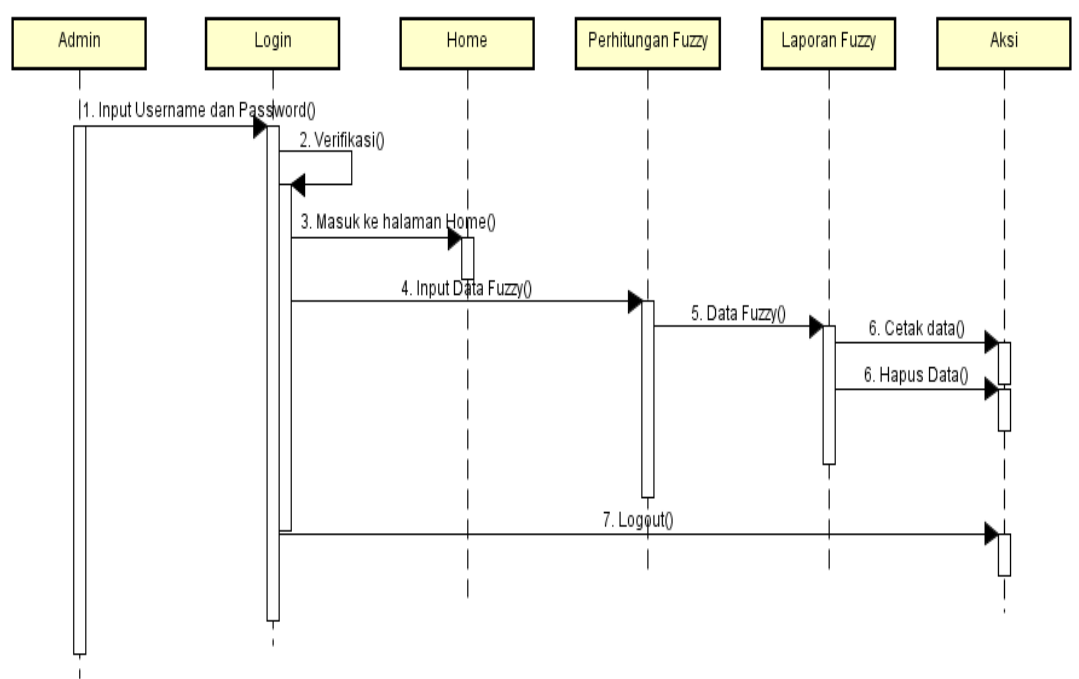

Gambar 3. Sequence Diagram

\subsubsection{Collaboration Diagram}

Collaboration diagram adalah cara alternative untuk mengetahui tahap-tahap terjadinya suatu aktivitas. Perbedaan antara collaboration dan sequence diagram adalah collaboration diagram memperlihatkan bagaimana hubungan antara beberapa objek berdasarkan urutan dari pesan, sedangkan sequence diagram memperlihatkan bagaimana urutan kejadian berdasarkan waktu.

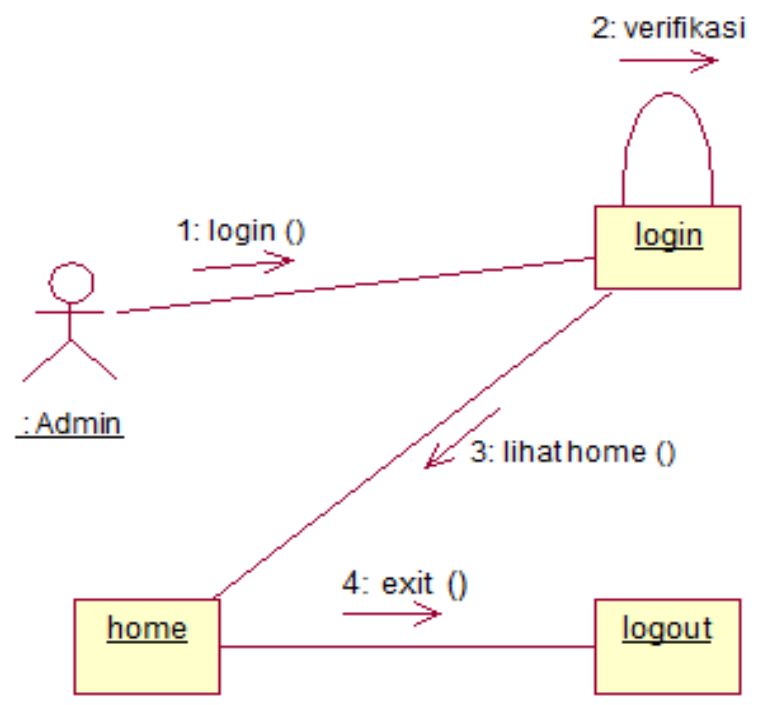

Gambar 4. Collaboration Diagram Home Admin 


\subsubsection{Statechart Diagram}

Statechart diagram menelusuri individu-individu objek melalui keseluruhan daur hidupnya, menspesifikasikan semua urutan yang mungkin dari pesan-pesan yang akan diterima objek tersebut, bersamasama dengan tanggapan atas pesan-pesan tersebut.

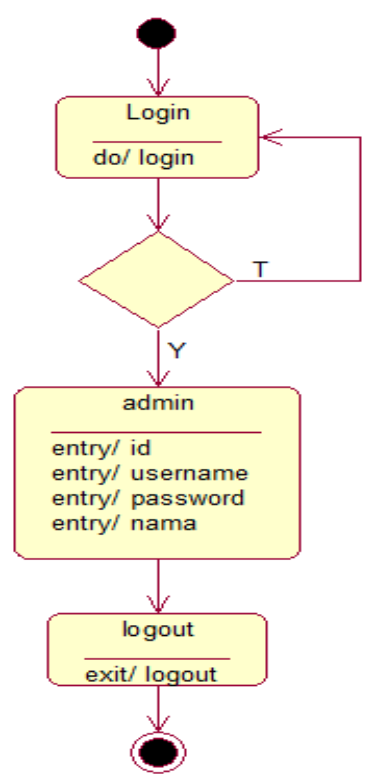

Gambar 5. Statechart Diagram Admin

\subsubsection{Activity Diagram}

Activity diagram merupakan sebuah diagram yang mendeskripsikan alur kerja dan aktifitas-aktifitas yang dapat dilakukan oleh aktor secara keseluruhan. Activity diagram menggambarkan bagaimana aktivitas yang terjadi dalam sistem yang akan dirancang. Activity diagram sama seperti halnya flowchart yang menggambarkan proses yang terjadi antara aktor dan sistem.

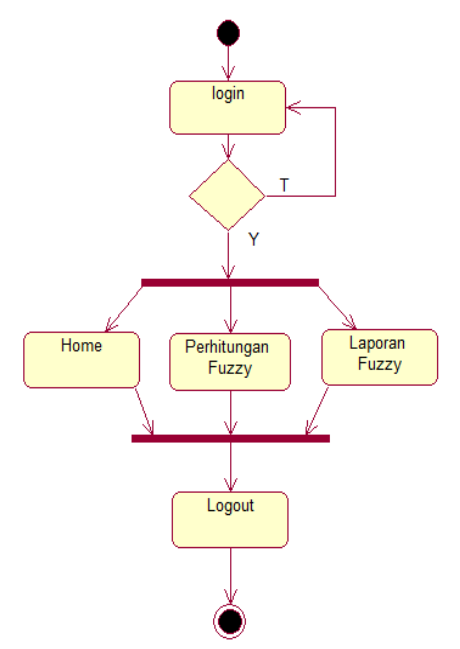

Gambar 6. Activity Diagram Admin 
Activity diagram admin mendeskripsikan alur kerja dan aktifitas-aktifitas yang dapat dilakukan oleh admin terhadap sistem sekaligus reaksi sistem terhadap aktifitas yang dilakukan oleh admin.

\subsubsection{Deployment Diagram}

Deployment diagram digunakan untuk menunjukan tata letak sebuah sistem secara fisik, dengan menampakkan bagian-bagian sofware yang berjalan pada bagian-bagian hardware, adapun gambar deployment diagram dapat dilihat pada gambar berikut:

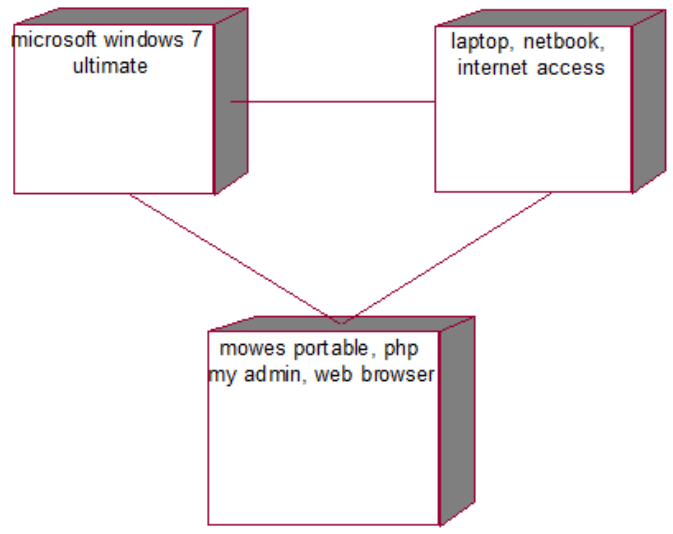

Gambar 7. Deployment Diagram

\section{IMPLEMENTASI SISTEM}

\subsection{Implementasi Sistem}

Implementasi sistem merupakan bagian dari siklus hidup pengembangan sistem, untuk melakukan sebuah implementasi maka diperlukan program komputer yaitu perancangan interface dan penulisan kode program sesuai dengan sistem yang telah dirancang.

\subsection{Pengujian Aplikasi}

Pada tahap ini, penulis melakukan pengujian menggunakan localhost, seperti gambar berikut :

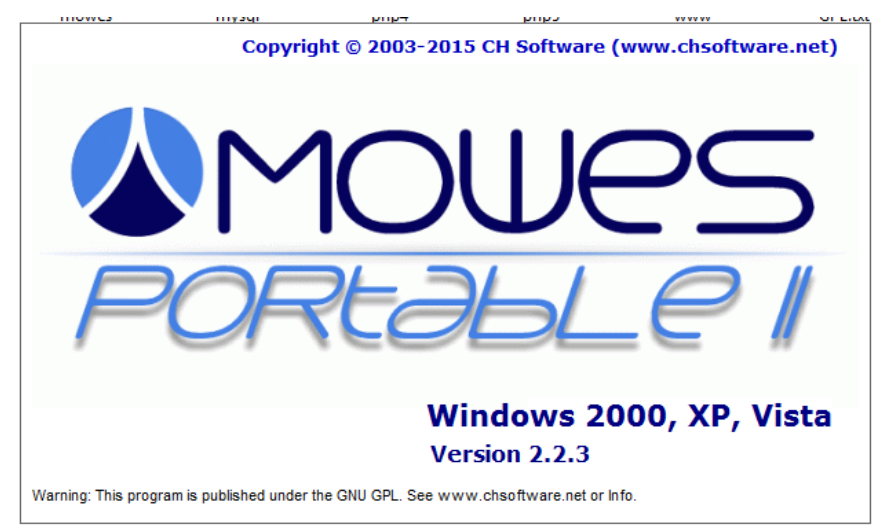

Gambar 7. Loading Mengaktifkan Mowes Portable 
MoWeS Portable II - (c) CH Software 2003-2015

Minimize Options Backup About Update Help End

\section{MoWes Portable II - Status}

Apache is running...

MySQL is running...

Stop server

Want to test MoWeS Portable III Alpha? Click here.

Gambar 8. Tampilan Mowes Portable

\section{SELAMAT DATANG}

HANYA untuk yang bersangkutan !!!

HARAP masukkan Username \& password nya. sekian terima kasih !!!

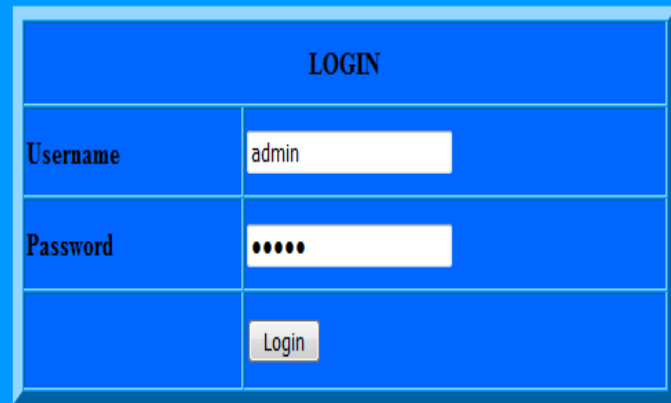

Gambar 9. Tampilan Login

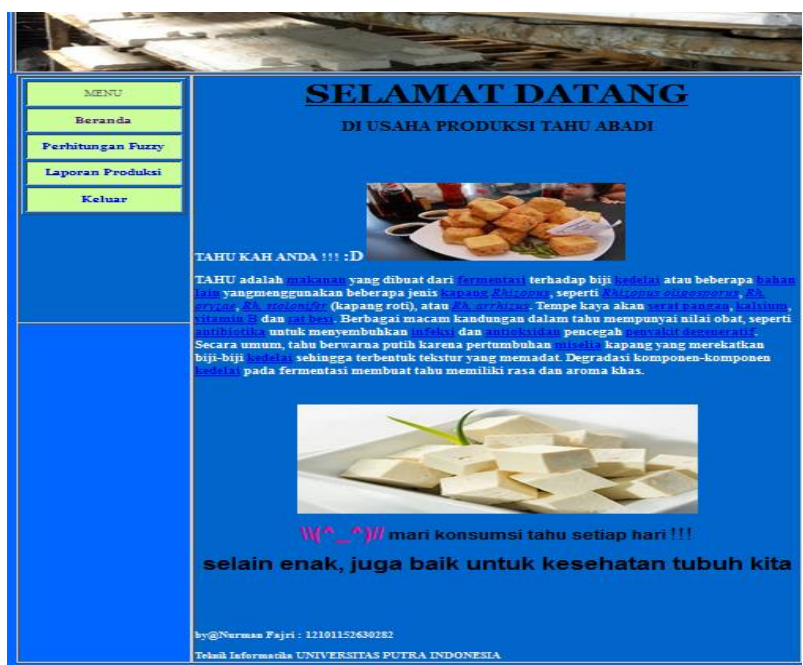

Gambar 10. Tampilan Halaman Utama

Penentuan Jumlah Produksi Tahu dengan Menggunakan Metode Fuzzy Tsukamoto Pada UKM Abadi Berbasis Web - (Wanda Ilham, Nurman Fajri) 


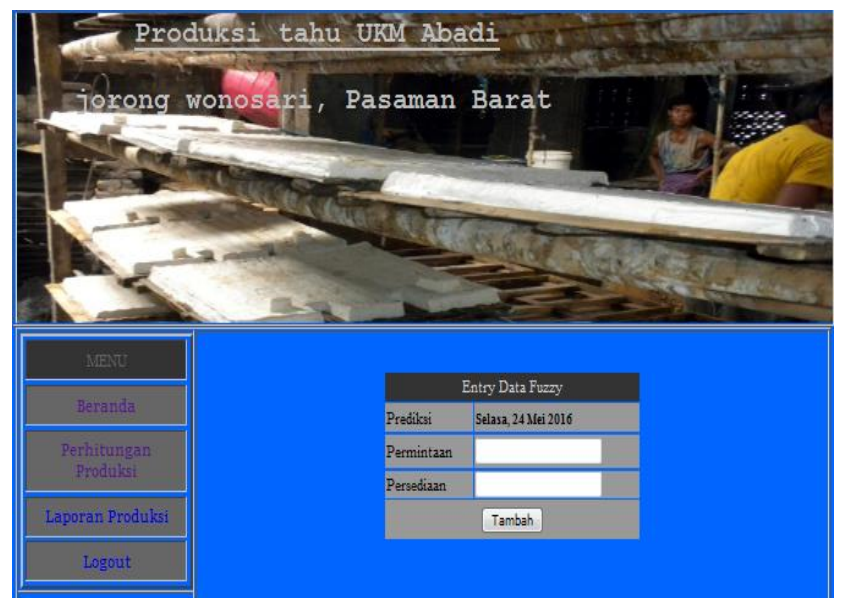

Gambar 11. Tampilan Perhitungan Fuzzy

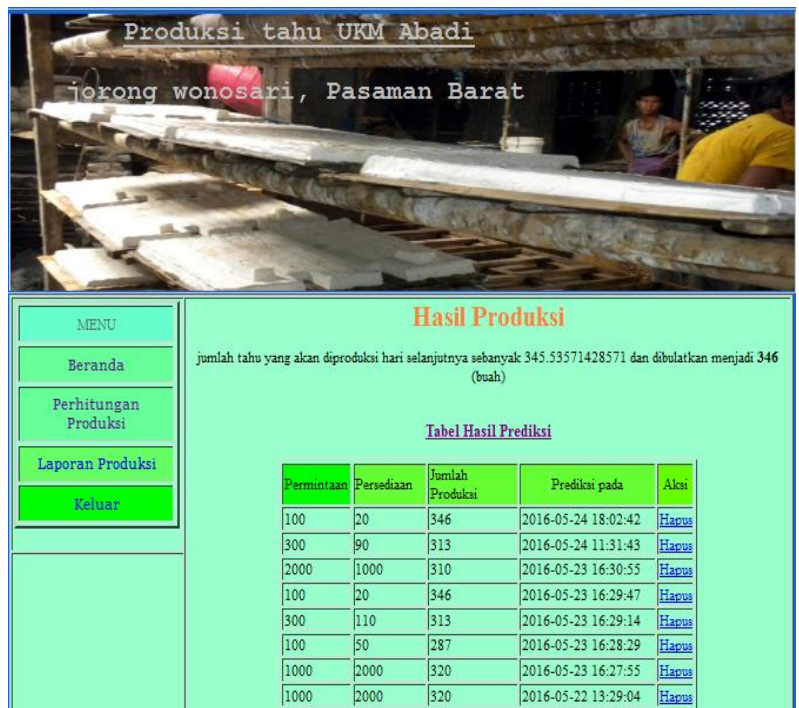

Gambar 12. Tampilan Laporan Fuzzy

Tabel 2. Tampilan tabel hasil pengujian

\begin{tabular}{|l|c|c|c|c|}
\hline \multirow{2}{*}{$\begin{array}{l}\text { Tanggal } \\
\text { Prediksi }\end{array}$} & Permintaan & Persediaan & \multicolumn{2}{|c|}{ Jumlah Produksi } \\
\cline { 2 - 5 } & & $(K g)$ & Program & Manual \\
\hline $\begin{array}{l}2016-05- \\
25\end{array}$ & & & & \\
$12: 16: 35$ & 7370 & 2500 & 7642 & 7642.35941 \\
\hline $\begin{array}{l}2016-05- \\
22\end{array}$ & & & & \\
$13: 23: 32$ & 7350 & 2450 & 7639.2031 & 7639.1791 \\
\hline
\end{tabular}




\section{KESIMPULAN DAN SARAN}

\subsection{Kesimpulan}

Setelah merancang Aplikasi Fuzzy Untuk menentukan jumlah produksi tahu ,pada UKM Abadi

Berbasis Web Menggunakan Metode Tsukamoto, penulis dapat menyimpulkan sebagai berikut :

1. Aplikasi ini dapat menentukan jumlah produksi berdasarkan data permintaan dan persediaan menggunakan fuzzy logic metode Tsukamoto pada UKM Abadi menjadi lebih akurat, stabil dan optimal.

2. Aplikasi fuzzy logic yang dirancang untuk menentukan jumlah produksi tahu pada UKM Abadi dapat mencapai jumlah produksi yang diharapkan.

3. Penerapan metode fuzzy logic dapat memonitoring kestabilan aktifitas produksi tahu dan dapat membantu penentuan jumlah produksi tahu pada usaha kecil dan menengah Abadi.

\subsection{Saran}

Setelah penulis menyelesaikan tahap akhir dari penelitian ini, penulis menyadari masih banyak kekurangan-kekurangan yang mesti diperbaiki dan dipenuhi, antara lain:

1. Diharapkan adanya pengembangan lain pada aplikasi fuzzy logic ini sehingga kedepannya dapat meningkatkan efektivitas dan efesiensi kinerja pada Usaha Kecil dan Menengah Abadi.

2. Disarankan agar sistem yang dibuat menambahkan fitur-fitur baru sesuai dengan perubahan kebutuhan perusahaan.

3. Diperlukan perawatan atau maintenance terhadap aplikasi fuzzy logic yang dibangun ini, guna meningkatkan kinerja dan layanan yang lebih baik pada Usaha Kecil dan Menengah Abadi.

\section{DAFTAR PUSTAKA}

[1] A.S, Rosa \& Shalahuddin M. (2013). Modul Pembelajaran Rekayasa Perangkat Lunak (Terstruktur dan Berorientasi Objek). Bandung: Informatika..

[2] Kusumadewi, Sri, 2000, "Perancangan Sistem fuzzy : Studi Kasus Prediksi Jumlah Produksi dan Harga Jual Barang” dalam Jurnal Teknologi Industri Volume 5, No.1. Jogjakarta:Ward J, Peppard J. Strategic planning for Information Systems. Fourth Edition. West Susse: John Willey \& Sons Ltd. 2007: 102-104.

[3] Kusumadewi, Sri. 2003. Artificial Intelligence (Teknik dan Aplikasinya). Yogyakarta: Graha Ilmu.

[4] Kusumadewi Sri. \& Hari Purnomo. (2004). Aplikasi Logika Fuzzy Untuk Sistem Pendukung Keputusan (Fuzzy Logic Applications for Decision Support Systems). Edisi Pertama (First Edition). Penerbit Graha Ilmu (Graha Sciences Publishers): Yogyakarta.

[5] Mandala, Eka Praja Wiyata. 2015. Web Programming ( Project 1 e.p.w.m Forum ).

[6] Peranginangin, Kasiman (2006). Aplikasi Web dengan PHP dan MySQL. Yogyakarta: Penerbit Andi.

[7] Pressman, Roger S. 2002. Rekayasa Perangkat Lunak: Pendekatan Praktisi (Buku 1)/ Roger S. Pressman; Diterjemahkan oleh: LN Harnaningrum. Yogyakarta: Andi.

[8] Suparman \& Marlan 2007, Komputer Masa Depan Pengenalan Artificial Intelligence, Andi Offset, Yogyakarta.

[9] Sutojo, T, Mulyanto, Edi dan Suharto, Vincent. (2011). Kecerdasan Buatan. Yogyakarta: Penerbit Andi.

[10] Djunaedi, Much., Setiawan, Eko, dan Andistas, Fajar Whedi. 2005. Penentuan Jumlah Produksi Dengan Aplikasi Metode Fuzzy Mamdani. Jurnal Ilmiah Teknik Industri 4: hal. 95-104. Surakarta: Jurusan Teknik Industri, Universitas Muhammadiyah Surakarta.

[11] Ilham, W. (2020). PENERAPAN METODE FUZZY TSUKAMOTO UNTUK MEMPREDIKSI ANGKA PRODUKSI RENDANG PADA TOKO RENDANG ASESE PADANG BERBASIS PHP MySQL. Jurnal Digit, 9(1), 84-96.

[12] Nas C. Sistem Pakar Diagnosa Penyakit Tiroid Menggunakan Metode Dempster Shafer. Jurnal Teknologi Dan Open Source. 2019; 2(1): 1-14. ISSN 2655-7592 